\title{
Efficient Synthesis of Functionalized 1,2,3-Triazoles by Catalyst-Free 1,3-Dipolar Cycloaddition of Nitroalkenes with Sodium Azide
}

\author{
Ting Wang, Xiao-Chun Hu,* Xu-Jiao Huang, Xin-Sheng Li and Jian-Wu Xie* \\ Key Laboratory of the Ministry of Education for Advanced Catalysis Materials, \\ Department of Chemistry and Life Science, Zhejiang Normal University, 321004 Jinhua, P. R. of China
}

Foi desenvolvido um protocolo simples e eficiente para a síntese de derivados de 1,2,3-triazol pela cicloadição 1,3-dipolar de nitroalquenos com azida de sódio, sem a necessidade de catalisador e sob condições brandas.

A simple and efficient protocol has been developed for the synthesis of 1,2,3-triazole derivatives by catalyst-free 1,3-dipolar cycloaddition of nitroalkenes with sodium azide under mild conditions.

Keywords: 1,2,3-triazoles, 1,3-dipolar cycloaddition, 3-nitrocoumarins, sodium azide, catalyst-free

\section{Introduction}

Five-membered nitrogen heterocycles play an important role in biological systems. Among these, the 1,2,3-triazoles and their derivatives are of considerable interest as they possess a wide range of biological properties, such as anti-HIV, ${ }^{1}$ anti-allergic, ${ }^{2}$ anti-fungal, ${ }^{3}$ anti-viral ${ }^{4}$ and anti-microbial activity. ${ }^{5} 1,2,3$-Triazoles are important in pharmacological applications due to its stability toward light, moisture, oxygen, and metabolism in the body. ${ }^{6}$ In addition, these moieties are widely applied as photosensitizers, dyes, ${ }^{7}$ and commercially employed as anti-corrosive agents ${ }^{8}$ in industry. Owing to the importance of these compounds, a variety of methods are known in the literature for the synthesis of pyrazoles, which include the thermal 1,3-dipolar cycloaddition of azide with various alkynes $^{9}$ and cycloaddition reactions of terminal alkynes with alkyl azides using $\mathrm{Cu}(\mathrm{I})$ as catalyst. ${ }^{10}$ In addition, these molecules can also be prepared in one-pot procedure from alkynes with azides. ${ }^{11}$ In fact, a straightforward approach to 1,2,3-triazoles is interesting and catalystfree intermolecular 1,3-dipolar cycloaddition azides with electron-deficient alkenes to afford 1,2,3-triazoles, has been the subject of intensive research. ${ }^{12}$ Recently, sodium azide has been used as a 1,3-dipole in 1,3-dipolar cycloaddition for the synthesis of 1,2,3-triazoles. ${ }^{12}$ Considering the above reports and encouraged by the good results, we envisaged

*e-mail: sky34@zjnu.cn, xiejw@zjnu.cn that 1,3-dipolar cycloaddition would be possible between the $\alpha$-carbonyl- $\beta$-aryl analogs of nitroethene with sodium azide, as outlined in Scheme 1. First, the reaction was happened via 1,3-dipolar cycloaddition of nitroalkenes with sodium ion as the key step. Then, elimination of the $\mathrm{NaNO}_{2}$ and migration of hydrogen atom afford 1,2,3-triazoles.

\section{Results and Discussion}

Coumarins are important heterocycles widely present in natural products exhibiting a broad range of biological and therapeutic activities and have been the subject of intensive research. ${ }^{13}$ Recently, we have demonstrated the usefulness of the catalyst-free intermolecular 1,3-dipolar cycloaddition of 3-nitrocoumarins in the synthesis of functionalized pyrazoles with good yields. ${ }^{14} \mathrm{We}$ considered that the incorporation of a 1,2,3-triazole heterocyclic unit into 3-nitrocoumarins might provide 1,2,3-triazole derivatives that have important biological and pharmaceutical activities. Thus, we turned our attention to the possible synthesis of 1,2,3-triazoles using 3-nitrocoumarins $\mathbf{1}$ as dipolarophiles for the electron-poor 3-nitrocoumarins is a good dipolarophile with a good leaving group $\mathrm{NO}_{2}$. The initial investigation started from the reaction between sodium azide and 3-nitrocoumarin 1a (Table 1). It is known from the literature that the optimal medium for the reaction of sodium azide with nitroalkenes is DMSO. ${ }^{13}$ Then we studied the reaction at different temperatures in DMSO, and found out that the best yield was obtained at $80^{\circ} \mathrm{C}$ after 


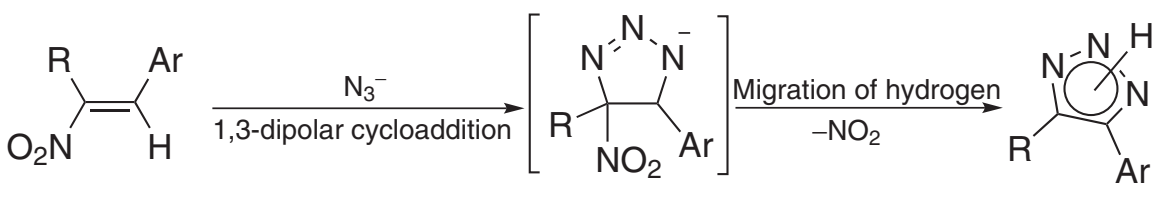

Scheme 1 .

$1 \mathrm{~h}$ (Table 1, entry 3 ). The structure was determined on the basis of ${ }^{1} \mathrm{H}$ NMR in comparison with the literature data. ${ }^{15}$

Table 1. Catalyst-free 1,3-dipolar cycloaddition of nitroalkenes with sodium azide under different conditions ${ }^{\mathrm{a}}$

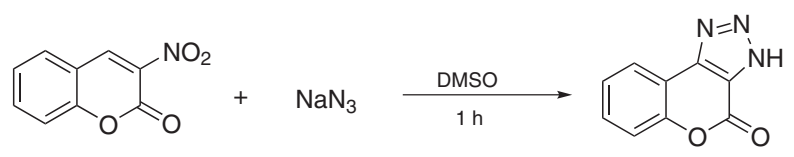

1a

$2 \mathbf{a}$

\begin{tabular}{lcc}
\hline Entry & $\mathrm{T} /{ }^{\circ} \mathrm{C}$ & Yield $^{\mathrm{b}} / \%$ \\
\hline 1 & 25 & trace \\
2 & 50 & 53 \\
3 & 80 & 89 \\
\hline
\end{tabular}

a Otherwise noted, reactions performed with $0.1 \mathrm{mmol}$ of $\mathbf{1 a}, 0.1 \mathrm{mmol}$ of $\mathrm{NaN}_{3}$ in $1 \mathrm{~mL}$ solvent. ' Isolated yield.
Under the optimized conditions, these findings could be extended to the application of various other 3-nitrocoumarins 1a-1e, and the 1,3-dipolar cycloaddition of 3-nitrocoumarins 1 to sodium azide proceeded smoothly to afford the chromeno[3,4-d][1,2,3]triazol-4(3H)-ones $\mathbf{2 a - 2 e}$ as single regioisomers. The reaction's scope proved to be broad with respect to the 3-nitrocoumarins $\mathbf{1}$. Good yields were obtained in the reactions of electron-withdrawing substituent on the aryl ring of 3-nitrocoumarins 1 with sodium azide (Table 2). In addition, an electron-donating substituent on the aryl ring of 3-nitrocoumarins 1 substrates tended to decrease their reactivity (Table 2 , entry 5 ).

Having succeeded in synthesizing tricyclic 1,2,3-triazole derivatives, we then turned our attention to extend the scope of the 1,3-dipolar cycloaddition further. Acyclic $\alpha$-carbethoxy-1-nitroalkenes $\mathbf{1 f}-\mathbf{1} \mathbf{j}$ were utilized as

Table 2. Reaction scopes of 3-nitrocoumarins 1 with sodium azide in DMSO at $80^{\circ} \mathrm{C}^{\mathrm{a}}$

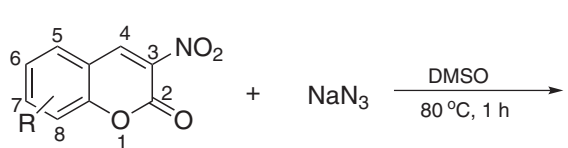

1<smiles>O=c1oc2ccccc2c2nn[nH]c12</smiles>

2

Entry

atherwise noted, reactions performed with $1 \mathrm{mmol}$ of $\mathbf{1}$ and $2 \mathrm{mmol}$ of $\mathrm{NaN}_{3}$ in $2 \mathrm{~mL} \mathrm{DMSO}$ at $80^{\circ} \mathrm{C}$ for $1 \mathrm{~h}$. ${ }^{\text {b Isolated yield. }}$ 
Table 3. Reaction scopes of acyclic $\alpha$-carbethoxy-1-nitroalkenes $\mathbf{1 f}-\mathbf{1 j}$ with sodium azide in DMSO at $50{ }^{\circ} \mathrm{C}^{\mathrm{a}}$

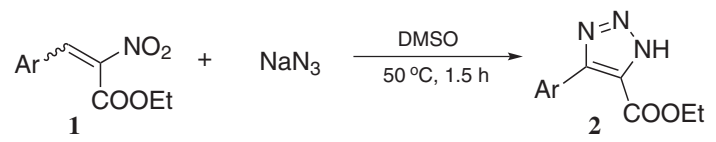

Entry

a Otherwise noted, reactions performed with $1 \mathrm{mmol}$ of $\mathbf{1}, 2 \mathrm{mmol}$ of $\mathrm{NaN}_{3}$ in $2 \mathrm{~mL} \mathrm{DMSO}$ at $50{ }^{\circ} \mathrm{C}$ for $1.5 \mathrm{~h}$. ${ }^{\mathrm{b}}$ Isolated yield.

dipolarophiles in the reaction with sodium azide. Unfortunately, very poor results were observed when the 1,3-dipolar cycloaddition of $\mathbf{1} \mathbf{f}-\mathbf{1} \mathbf{j}$ with sodium azide was carried out at $80^{\circ} \mathrm{C}$. To our delight, good yields were obtained when the reactions were carried out at $50{ }^{\circ} \mathrm{C}$ after $1 \mathrm{~h}$ (Table 3). Table 3 shows that $\alpha$-carbethoxy-1nitrostyrenes with electron-withdrawing or donating substituents provided the 1,2,3-triazole derivatives $2 \mathbf{2}-\mathbf{2} \mathbf{i}$ in moderate-to-good yields of $62-76 \%$ (entries 2-4). The structures were also determined on the basis of ${ }^{1} \mathrm{H}$ NMR in comparison with the literature data. ${ }^{15}$

To explain the key step of the reaction between azidium ion and nitroalkenes, B3LYP/6-31g (d) calculations of stationary structures of azidium ion and nitroalkenes (1a-j) have been performed. It turned out that the global electrophilicity of azidium ion equals to $1.6 \mathrm{eV}$. At the same time it shows a strongly nucleophilic ${ }^{16}$ characteristics $(\mathrm{N}=7.97 \mathrm{eV})$. The nitrocoumarines (1a-e), on the other hand, show strongly electrophilic properties (global electrophilicity of $(\mathbf{1 a})=3.28,(\mathbf{1 b})=3.55,(\mathbf{1} \mathbf{c})=3.62$, $(\mathbf{1 d})=3.62,(\mathbf{1 e})=2.94 \mathrm{eV})$. Their electrophilicity is therefore much higher than of the corresponding $\beta$-nitrostyrenes ${ }^{17}$ and only slightly lower than of the corresponding $\beta$-cyano- $\beta$-nitrostyrenes. ${ }^{18}$ In the case of a series of $\beta$-carboethoxy- $\beta$-nitrostyrenes global electrophilicity is significantly lower (in particular: $(\mathbf{1 i})=2.64,(\mathbf{1 f})=2.72$, $(\mathbf{1 g})=2.93,(\mathbf{1 h})=2.93 \mathrm{eV})$, but remain in the range typical for the strongly electrophilic dipolarophiles. ${ }^{19}$ Notably, these reactions can be considered as polar1,3dipolar cycloaddition (P-13DC). ${ }^{20}$ Detailed analysis of the local electrophilicity indices on the reaction centers of nitroalkenes also revealed that the reaction was determined by the attack of nucleophilic atom of 1,3-dipole to $\beta$-position of nitroalkene, similarly as in the reactions of nitroethene with nitrones. ${ }^{21}$

\section{Conclusions}

In conclusion, an efficient method for the synthesis of functionalized 1,2,3-triazoles by catalyst-free 1,3-dipolar cycloaddition of nitroalkenes with sodium azide has been investigated. The 1,3-dipolar cycloaddition can proceed smoothly under mild conditions and provides pure 1,2,3-triazole derivatives in good yields. The reaction's scope proved to be quite broad. Notably, we incorporated a 1,2,3-triazole heterocyclic unit into coumarins and provided substituted chromeno[3,4-d][1,2,3] triazol-4(1H)-one that might have important biological and pharmaceutical 
activities in the future. This novel methodology should be of great interest for natural product synthesis for the mild reaction conditions.

\section{Experimental}

All commercially available reagents and solvents were obtained from commercial providers and used without further purification. Reactions were monitored by TLC using silica gel 60 UV254 Macherey-Nagel pre-coated silica gel plates; detection was by means of a UV lamp. Column chromatography was performed using silica gel (200-300 mesh) eluting with ethyl acetate and petroleum ether. Organic layers were dried over anhydrous $\mathrm{MgSO}_{4}$ or $\mathrm{Na}_{2} \mathrm{SO}_{4}$ prior to evaporation on a rotary evaporator. ${ }^{1} \mathrm{H} \mathrm{NMR}$ spectra were recorded at $400 \mathrm{MHz}$, and ${ }^{13} \mathrm{C}$ NMR spectra were recorded at $100 \mathrm{MHz}$ (Bruker Avance). Chemical shifts $(\delta)$ are reported in ppm downfield from $\mathrm{CDCl}_{3}(\delta 7.26 \mathrm{ppm})$ for ${ }^{1} \mathrm{H}$ NMR and relative to the central $\mathrm{CDCl}_{3}$ resonance ( $\delta 77.0 \mathrm{ppm}$ ) for ${ }^{13} \mathrm{C}$ NMR spectroscopy. Coupling constants $(J)$ are given in Hz. ESI-HRMS spectrometer was measured with a Finnigan $\mathrm{LCQ}^{\mathrm{DECA}}$ ion trap mass spectrometer. 2-Aryl1-carboethoxy-1-nitroethenes $\mathbf{1}$ were prepared according to reported procedure. ${ }^{22}$ Triazoles $\mathbf{2 a}, \mathbf{2 c}, \mathbf{2 e}, \mathbf{2 f}$ and $\mathbf{2 g}$ are known compounds. ${ }^{15}$ Triazoles $\mathbf{2 b}, \mathbf{2 d}$ and $\mathbf{2 h}-\mathbf{j}$ are new compounds and their physical and spectral properties are reported in Supplementary Information section.

General procedure for the synthesis of 1,2,3-triazoles 2 under the optimized conditions

To the solution of the nitroalkenes 1 ( $1 \mathrm{mmol}$ ) in DMSO $(2 \mathrm{~mL})$ was added sodium azide $(2 \mathrm{mmol})$. The mixture was then heated at $80^{\circ} \mathrm{C}$ until the starting material was totally consumed as indicated by TLC. After cooling, water was added and the resulting precipitate was filtered, washed with excess of water, and dried to give the desired triazole, which was recrystallized. When no precipitate was observed, the triazole was isolated after extraction with ethylacetate. Further purification was done by column chromatography using ethylacetate/petroleum ether as eluent.

\section{Supplementary Information}

Supplementary data are available free of charge at http://jbcs.sbq.org.br as PDF file.

\section{Acknowledgments}

We are grateful for the financial support from China (NSFC: 20902083 and NSFZPY: 4090082).

\section{References}

1. Alvarez,R.; Velazquez, S.; San, F.;Aquaro, S.; De, C.; Perno, C.F.; Karlsson, A.; Balzarini, J.; Camarasa, M. J.; J. Med. Chem. 1994, 37, 4185.

2. Buckle, D. R.; Rockell, C. J. M.; Smith, H.; Spicer, B. A.; J. Med. Chem. 1986, 29, 2262.

3. Vicentini, C. B.; Brandolini, V.; Guarneri, M.; Giori, P.; Farmaco 1992, 47, 1021; Joan, C. F. T.; Elizabeth, H.; Beatrice, M.; Daniel, P. B.; Antimicrob. Agents Chemother. 1998, 42, 313.

4. Palhagen, S.; Canger, R.; Henriksen, O.; van Parys, J. A.; Riviere, M. E.; Karolchyk, M. A.; Epilepsy Res. 2001, 43, 115.

5. Genin, M. J.; Allwine, D. A.; Anderson, D. J.; Barbachyn, M. R.; Emmert, D. E.; Garmon, S. A.; Graber, D. R.; Grega, K. C.; Hester, J. B.; Hutchinson, D. K.; Morris, J.; Reischer, R. J.; Ford, C. W.; Zurenko, G. E.; Hamel, J. C.; Schaadt, R. D.; Stapert, D.; Yagi, B. H.; J. Med. Chem. 2000, 43, 953.

6. Bourne, Y.; Kolb, H. C.; Radic, Z.; Sharpless, K. B.; Taylor, P.; Marchot, P.; Proc. Natl. Acad. Sci. U. S. A. 2004, 101, 1449.

7. Willis, R. J.; Marlow, I. D.; Eur. Pat. Appl. 400842, 1990. (CA 1991, 114, 164247b)

8. Morgan, N. H.; (CHOMERICS) Eur. Pat. Appl. EP 437979 A2 19910724, 1991.

9. Huisgen, R.; Szeimies, G.; Moebius, L.; Chem. Ber. 1967, 100, 2494; Huisgen, R.; 1,3-Dipolar Cycloaddition Chemistry, Wiley: New York, NY, 1984, pp. 1-176; Huisgen, R.; Pure Appl. Chem. 1989, 61, 613.

10. Kolb, H. C.; Finn, M. G.; Sharpless, K. B.; Angew. Chem., Int. Ed. 2001, 40, 2004.

11. Beckmann, H. S. G.; Wittmann, V.; Org. Lett. 2007, 9, 1; Barral, K.; Moorhouse, A. D.; Moses, J. E.; Org. Lett. 2007, 9, 1809.

12. Zefirov, N. S.; Chapovskaya, N. K.; Kolesnikov, V. V.; Chem. Commun. 1971, 1001; Anisimova, N. A.; Berestovitskaya, V. M.; Berkova, G. A.; Makarova, N. G.; Russ. J. Org. Chem. 2007, 43, 652; Ugrak, B. I.; Zubanova, N. I.; Russ. Chem. Bull. 1992, 41, 751; Sheremet, E. A.; Tomanov, R. I.; Trukhin, E. V.; Berestovitskaya, V. M.; Russ. J. Org. Chem. 2004, 40, 594; Anisimova, N. A.; Makarova, N. G.; Berkova, G. A.; Berestovitskaya, V. M.; Russ. J. Gen. Chem. 2006, 76, 1545 .

13. Sugino, T.; Tanaka, K.; Chem. Lett. 2001, 513; Brufola, G.; Fringuelli, F.; Yavari, I.; Hekmat-Shoar, R.; Zonouzi, A.; Tetrahedron Lett. 1998, 39, 2391; Dittmer, D. C.; Li, Q.; Avilov, D. V.; J. Org. Chem. 2005, 70, 4682; Alexander, V. M.; Bhat, R. P.; Samant, S. D.; Tetrahedron Lett. 2005, 46, 6957; Jia, C.; Piao, D.; Kitamura, T.; Fujiwara, Y.; J. Org. Chem. 2000, 65, 7516; Selles, P.; Mueller, U.; Org. Lett. 2004, 6, 277; Li, K.; Zeng, Y.; Neuenswander, B.; Tunge, J. A.; J. Org. Chem. 2005, 70, 6515; Aoki, S.; Macloed, A. M.; Grimwood, S.; Barton, C.; Bristow, L.; Saywell, K.; Marshall, G. R.; Ball, G.; J. Med. Chem. 1995, 38, 2239. 
14. Xie, J.-W.; Wang, Z.; Yang, W.-J.; Kong, L.-C.; Xu, D.-C.; Org. Biomol. Chem. 2009, 7, 4352 .

15. D’Ambrosio G.; Fringuelli, F.; Pizzo F.; Vaccaro, L.; Green Chem. 2005, 7, 874; Haryu, K.; Vahermo, M.; Mutikainen, I.; Yli-Kauhauloma, J.; J. Comb. Chem. 2003, 5, 826; Amantini, D.; Fringuelli, F.; Piermatti, O.; Pizzo, F.; Zunino, E.; Vaccaro, L.; J. Org. Chem. 2005, 70, 6526.

16. Domingo, L. R.; Chamorro, E.; Pèrez, P.; J. Org. Chem. 2008, $73,4615$.

17. Jasiński, R.; Kwiatkowska, M.; Barański, A.; J. Phys. Org. Chem. 2011, 24, 843.
18. Jasiński, R.; Barański, A.; THEOCHEM 2010, 949, 8.

19. Pèrez, P.; Domingo, L. R.; Aurell, M. J.; Contreras, R.; Tetrahedron 2003, 59, 3117.

20. Domingo, L. R.; Sáez, J. A.; Org. Biomol. Chem. 2009, 7, 3576.

21. Jasiński, R.; Koifman, O. I.; Barański, A.; Mendeleev Commun. 2011, 21, 262.

22. Ploypradith, P.; Petchmanee, T.; Sahakitpichan, P.; Litvinas, N. D.; Ruchirawat, S.; J. Org. Chem. 2006, 71, 9440.

Submitted: December 13, 2011

Published online: May 24, 2012 


\title{
Efficient Synthesis of Functionalized 1,2,3-Triazoles by Catalyst-Free 1,3-Dipolar Cycloaddition of Nitroalkenes with Sodium Azide
}

\author{
Ting Wang, Xiao-Chun Hu,* Xu-Jiao Huang, Xin-Sheng Li and Jian-Wu Xie* \\ Key Laboratory of the Ministry of Education for Advanced Catalysis Materials, \\ Department of Chemistry and Life Science, Zhejiang Normal University, 321004 Jinhua, P. R. of China
}

\section{Experimental}

General methods

All commercially available reagents and solvents were obtained from commercial providers and used without further purification. Reactions were monitored by TLC using silica gel 60 UV254 Macherey-Nagel pre-coated silica gel plates; detection was by means of a UV lamp. Column chromatography was performed using silica gel (200-300 mesh) eluting with ethyl acetate and petroleum ether. Organic layers were dried over anhydrous $\mathrm{MgSO}_{4}$ or $\mathrm{Na}_{2} \mathrm{SO}_{4}$ prior to evaporation on a rotary evaporator. ${ }^{1} \mathrm{H}$ NMR spectra were recorded at $400 \mathrm{MHz}$, and ${ }^{13} \mathrm{C}$ NMR spectra were recorded at $100 \mathrm{MHz}$ (Bruker Avance). Chemical shifts $(\delta)$ are reported in ppm downfield from $\mathrm{CDCl}_{3}(\delta 7.26 \mathrm{ppm})$ for ${ }^{1} \mathrm{H} \mathrm{NMR}$ and relative to the central $\mathrm{CDCl}_{3}$ resonance $(\delta 77.0 \mathrm{ppm})$ for ${ }^{13} \mathrm{C}$ NMR spectroscopy. Coupling constants $(J)$ are given in Hz. ESI-HRMS spectrometer was measured with a Finnigan $\mathrm{LCQ}^{\mathrm{DECA}}$ ion trap mass spectrometer. Triazoles $\mathbf{2 a}, \mathbf{2 c}, \mathbf{2 e}, \mathbf{2 f}$ and $\mathbf{2 g}$ are known compounds. ${ }^{1}$ Triazoles $\mathbf{2 b}, \mathbf{2 d}$ and $\mathbf{2 h}-\mathbf{j}$ are new compounds and their physical and spectral properties are reported below.

A typical procedure for synthesis of $\mathbf{2 a - 2 e}$

To the solution of the nitroalkenes $\mathbf{1}(1 \mathrm{mmol})$ in DMSO ( $2 \mathrm{~mL}$ ) was added sodium azide $(2 \mathrm{mmol})$. The mixture was then heated at $80{ }^{\circ} \mathrm{C}$ until the starting material was totally consumed as indicated by TLC. After cooling, water was added and the resulting precipitate was filtered, washed with excess of water, and dried to give the desired triazole, which was recrystallized. When no precipitate was observed, the triazole was isolated after extraction with ethylacetate.

*e-mail: sky34@zjnu.cn, xiejw@ zjnu.cn
Further purification was done by column chromatography using ethylacetate/petroleum ether as eluent.

Chromeno[3,4- $d][1,2,3]$ triazol-4(3H)-one $(2 \mathbf{a})^{1}$

${ }^{1} \mathrm{H}$ NMR (400 MHz, DMSO) $\delta 8.03(\mathrm{~d}, 1 \mathrm{H}, J 7.7 \mathrm{~Hz})$, 7.64 (dd, 1H, J 11.4, 4.2 Hz), 7.53 (d, 1H, J 8.3 Hz), 7.47 (t, 1H, J $7.5 \mathrm{~Hz})$.

8-Fluorochromeno[3,4- $d][1,2,3]$ triazol-4(3H)-one (2b)

Solid, mp $315^{\circ} \mathrm{C}$ (dec.). ${ }^{1} \mathrm{H}$ NMR (400 MHz, DMSO-d $)$ $\delta 7.75(\mathrm{~m}, 1 \mathrm{H}), 7.56(\mathrm{~m}, 1 \mathrm{H}), 7.47(\mathrm{~m}, 1 \mathrm{H}) ;{ }^{13} \mathrm{C} \mathrm{NMR}$ $\left(100 \mathrm{MHz}, \mathrm{DMSO}-d_{6}\right) \delta 164.7,162.3,159.5,153.8,124.7$, 124.0, 123.7, 114.5, 114.3; IR (KBr) $v_{\max } / \mathrm{cm}^{-1}: 856,1009$, 1140, 1472, 1523, 1642, 1744, 3215; ESI-HRMS: calc. for $\mathrm{C}_{9} \mathrm{H}_{4} \mathrm{FN}_{3} \mathrm{O}_{2}+\mathrm{Na} 228.0181$, found 228.0178.

8-Chlorochromeno[3,4- $d][1,2,3]$ triazol-4(3H)-one (2c) ${ }^{1}$

${ }^{1} \mathrm{H}$ NMR (400 MHz, DMSO) $\delta 8.07$ (d, 1H, J 2.5 Hz), 7.56 (dd, 1H, J 8.8, 2.3 Hz), 7.37 (d, 1H, J 8.8 Hz).

8-Bromochromeno[3,4- $d][1,2,3]$ triazol-4(3H)-one (2d)

Solid, mp $336{ }^{\circ} \mathrm{C}$ (dec.). ${ }^{1} \mathrm{H}$ NMR (400 MHz, DMSO- $d_{6}$ ) $\delta 7.98(\mathrm{~d}, 1 \mathrm{H}, J 2.3 \mathrm{~Hz}), 7.63(\mathrm{dd}, 1 \mathrm{H}, J 8.9,2.4 \mathrm{~Hz})$, 7.53 (d, 1H, J 8.9 Hz), 2.46 (s, 1H); ${ }^{13} \mathrm{C} \mathrm{NMR} \mathrm{(100} \mathrm{MHz,}$ DMSO- $\left.d_{6}\right) \delta 154.7,151.3,131.5,129.2,123.1,119.8$, 113.9; IR (KBr) $v_{\max } / \mathrm{cm}^{-1}: 848,1002,1131,1452,1513$, 1612, 1726, 3218; ESI-HRMS: calc. for $\mathrm{C}_{9} \mathrm{H}_{4} \mathrm{BrN}_{3} \mathrm{O}_{2}+\mathrm{Na}$ 287.9381 , found 287.9377 .

7-Methoxychromeno[3,4- $d][1,2,3]$ triazol-4(3H)-one $(2 \mathbf{e})^{1}$

${ }^{1} \mathrm{H}$ NMR (400 MHz, $\left.\mathrm{CDCl}_{3}\right) \delta 7.82(\mathrm{~d}, 1 \mathrm{H}, J 9.1 \mathrm{~Hz})$, $6.81(\mathrm{~d}, 2 \mathrm{H}, J 7.5 \mathrm{~Hz}), 3.76(\mathrm{~s}, 3 \mathrm{H})$.

A typical procedure for synthesis of $\mathbf{2} \mathbf{f}-\mathbf{j}$

To the solution of the nitroalkenes 1 ( $1 \mathrm{mmol}$ ) in DMSO ( $2 \mathrm{~mL}$ ) was added sodium azide $(2 \mathrm{mmol})$. The mixture was 
then heated at $50{ }^{\circ} \mathrm{C}$ until the starting material was totally consumed as indicated by TLC. After cooling, water was added and the resulting precipitate was filtered, washed with excess of water, and dried to give the desired triazole, which was recrystallized. When no precipitate was observed, the triazole was isolated after extraction with ethylacetate. Further purification was done by column chromatography using ethylacetate/petroleum ether as eluent.

Ethyl 5-phenyl-1 $\mathrm{H}$-1,2,3-triazole-4-carboxylate (2f) ${ }^{1}$

${ }^{1} \mathrm{H}$ NMR (400 MHz, DMSO- $\left.d_{6}\right) \delta$ 7.86-7.67 (m, 2H), 7.53-7.40 (m, 3H), 4.27 (m, 2H), $1.22(\mathrm{t}, 3 \mathrm{H}, J 7.1 \mathrm{~Hz})$.

Ethyl 5-(4-chlorophenyl)-1H-1,2,3-triazole-4-carboxylate $(2 \mathrm{~g})^{1}$

${ }^{1} \mathrm{H}$ NMR $\left(400 \mathrm{MHz}, \mathrm{DMSO}-d_{6}\right) \delta 7.80(\mathrm{~d}, 2 \mathrm{H}, J 8.4 \mathrm{~Hz})$, $7.55(\mathrm{~d}, 2 \mathrm{H}, J 8.6 \mathrm{~Hz}), 4.28(\mathrm{~m}, 2 \mathrm{H}), 1.25(\mathrm{t}, 3 \mathrm{H}, J 7.1 \mathrm{~Hz})$.

Ethyl 5-(4-bromophenyl)-1H-1,2,3-triazole-4-carboxylate (2h)

Solid, mp 173-174 ${ }^{\circ} \mathrm{C} .{ }^{1} \mathrm{H}$ NMR (400 MHz, DMSO- $d_{6}$ ) $\delta 7.73(\mathrm{~d}, 2 \mathrm{H}, J 8.1 \mathrm{~Hz}), 7.66(\mathrm{~d}, 2 \mathrm{H}, J 8.3 \mathrm{~Hz}), 4.28(\mathrm{dd}, 2 \mathrm{H}$, $J$ 14.1, 7.0 Hz), 1.24 (t, 3H, J 7.1 Hz); ${ }^{13} \mathrm{C} \mathrm{NMR} \mathrm{(100} \mathrm{MHz,}$ DMSO-d $\left.{ }_{6}\right) \delta 161.3,158.9,152.8,131.5,123.2,61.3,14.3$; $\operatorname{IR}(\mathrm{KBr}) v_{\max } / \mathrm{cm}^{-1}: 846,989,1141,1426,1532,1625,1730$, 2986; ESI-HRMS: calc. for $\mathrm{C}_{11} \mathrm{H}_{10} \mathrm{BrN}_{3} \mathrm{O}_{2}+\mathrm{Na} 294.9950$, found 294.9943 .

NMR spectra
Ethyl 5-(p-tolyl)-1 H-1,2,3-triazole-4-carboxylate (2i)

Solid, mp 297-298 ${ }^{\circ} \mathrm{C} .{ }^{1} \mathrm{H}$ NMR (400 MHz, DMSO- $d_{6}$ ) $\delta 7.66(\mathrm{~d}, 2 \mathrm{H}, J 7.6 \mathrm{~Hz}), 7.29(\mathrm{~d}, 2 \mathrm{H}, J 7.7 \mathrm{~Hz}), 4.28$ $(\mathrm{m}, 2 \mathrm{H}), 2.36(\mathrm{~s}, 3 \mathrm{H}), 1.25(\mathrm{t}, 3 \mathrm{H}, J 7.1 \mathrm{~Hz}) ;{ }^{13} \mathrm{C} \mathrm{NMR}$ $\left(100 \mathrm{MHz}, \mathrm{DMSO}-d_{6}\right) \delta 158.4,156.0,153.2,129.3,61.1$, 21.3, 14.4; IR (KBr) $v_{\max } / \mathrm{cm}^{-1}: 864,991,1145,1473,1536$, 1616, 1749, 2997; ESI-HRMS: calc. for $\mathrm{C}_{12} \mathrm{H}_{13} \mathrm{~N}_{3} \mathrm{O}_{2}+\mathrm{Na}$ 254.0902 , found 254.0897 .

Ethyl 5-(furan-2-yl)-1 H-1,2,3-triazole-4-carboxylate (2j)

Solid, mp 141-142 ${ }^{\circ} \mathrm{C} .{ }^{1} \mathrm{H}$ NMR (400 MHz, DMSO- $d_{6}$ ) $\delta 7.89(\mathrm{~s}, 1 \mathrm{H}), 7.37$ (s, 1H), $6.67(\mathrm{dd}, 1 \mathrm{H}, J 3.2,1.7 \mathrm{~Hz})$, $4.34(\mathrm{~m}, 2 \mathrm{H}), 1.30(\mathrm{t}, 3 \mathrm{H}, J 7.1 \mathrm{~Hz}) ;{ }^{13} \mathrm{C} \mathrm{NMR}(100 \mathrm{MHz}$, DMSO- $\left.d_{6}\right) \delta 160.9,154.3,144.9,129.5,113.6,112.5$, 110.1, 61.3, 14.5; IR (KBr) $v_{\max } / \mathrm{cm}^{-1}: 851,1007,1125$, 1453, 1526, 1609, 1750, 2996; ESI-HRMS: calc. for $\mathrm{C}_{9} \mathrm{H}_{9} \mathrm{~N}_{3} \mathrm{O}_{3}+\mathrm{Na} 230.0538$, found 230.0531.

\section{Reference}

1. D’Ambrosio, G.; Fringuelli, F.; Pizzo, F.; Vaccaro, L.; Green Chem. 2005, 7, 874; Haryu, K.; Vahermo, M.; Mutikainen, I.; Yli-Kauhauloma, J.; J. Comb. Chem. 2003, 5, 826; Amantini, D.; Fringuelli, F.; Piermatti, O.; Pizzo, F.; Zunino, E.; Vaccaro, L.; J. Org. Chem. 2005, 70, 6526.

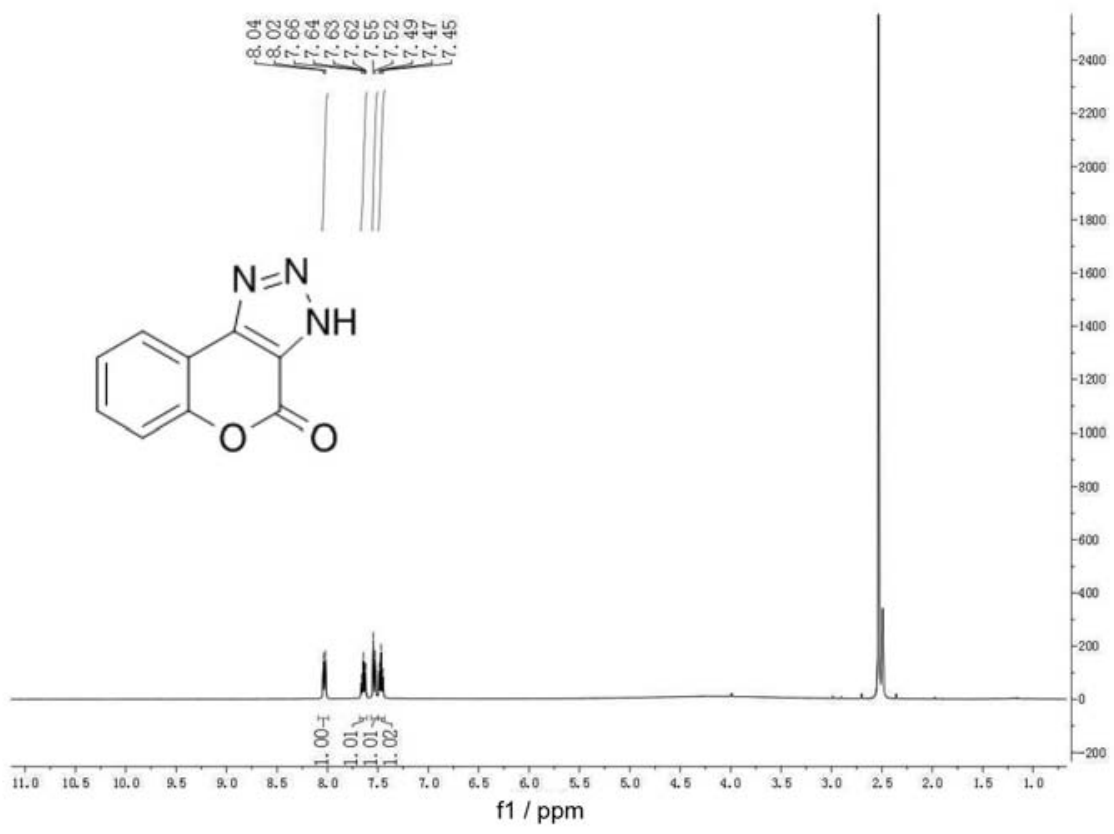

Figure S1. ${ }^{1} \mathrm{H}$ NMR spectrum (400 MHz, DMSO- $d_{6}$ ) of chromeno[3,4-d][1,2,3] triazol-4(3H)-one (2a). 

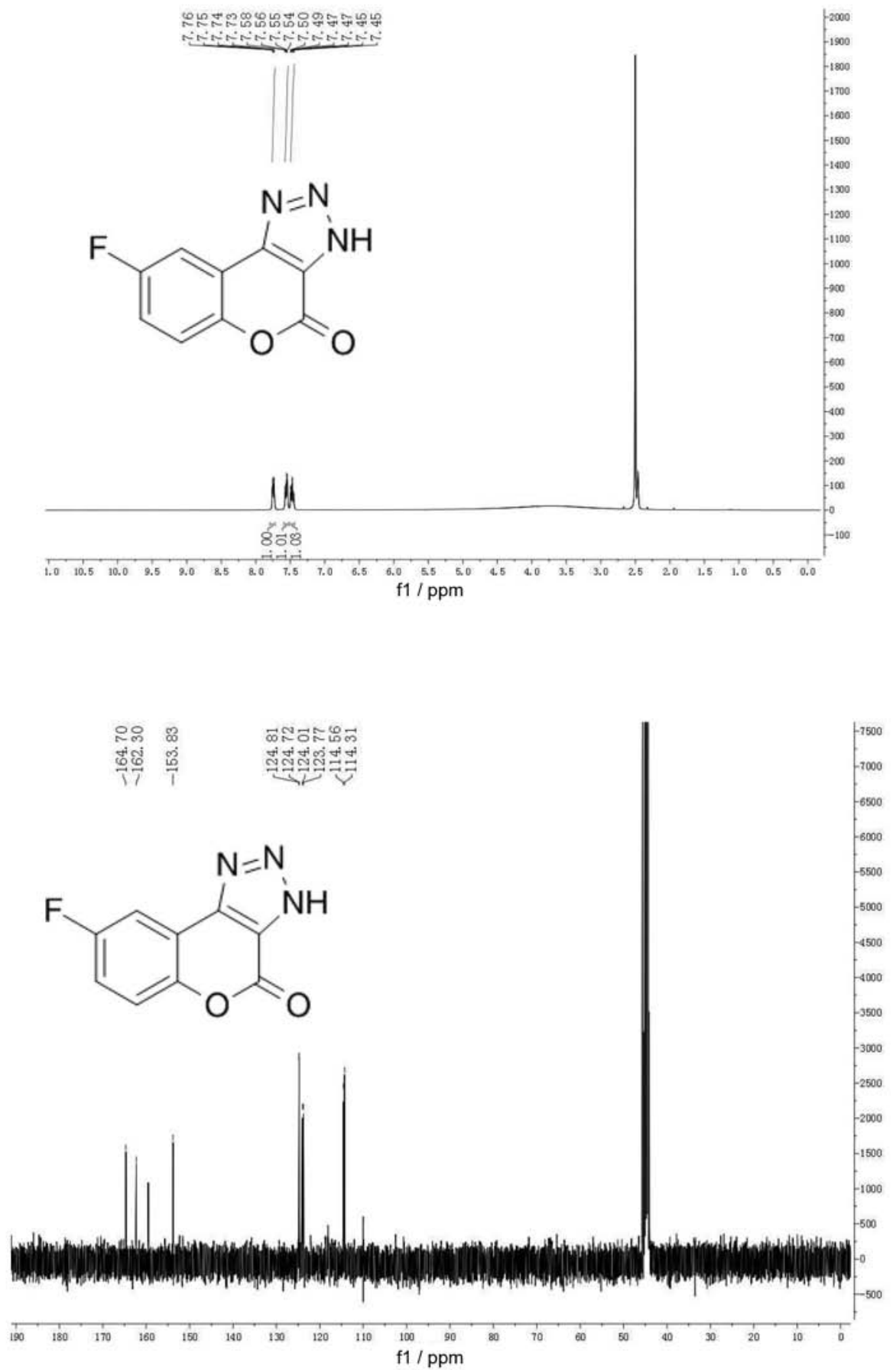

Figure S2. ${ }^{1} \mathrm{H}$ NMR and ${ }^{13} \mathrm{C}$ NMR spectra (400 MHz, DMSO- $d_{6}$ ) of fluorochromeno[3,4-d] $[1,2,3]$ triazol-4(3H)-one (2b). 


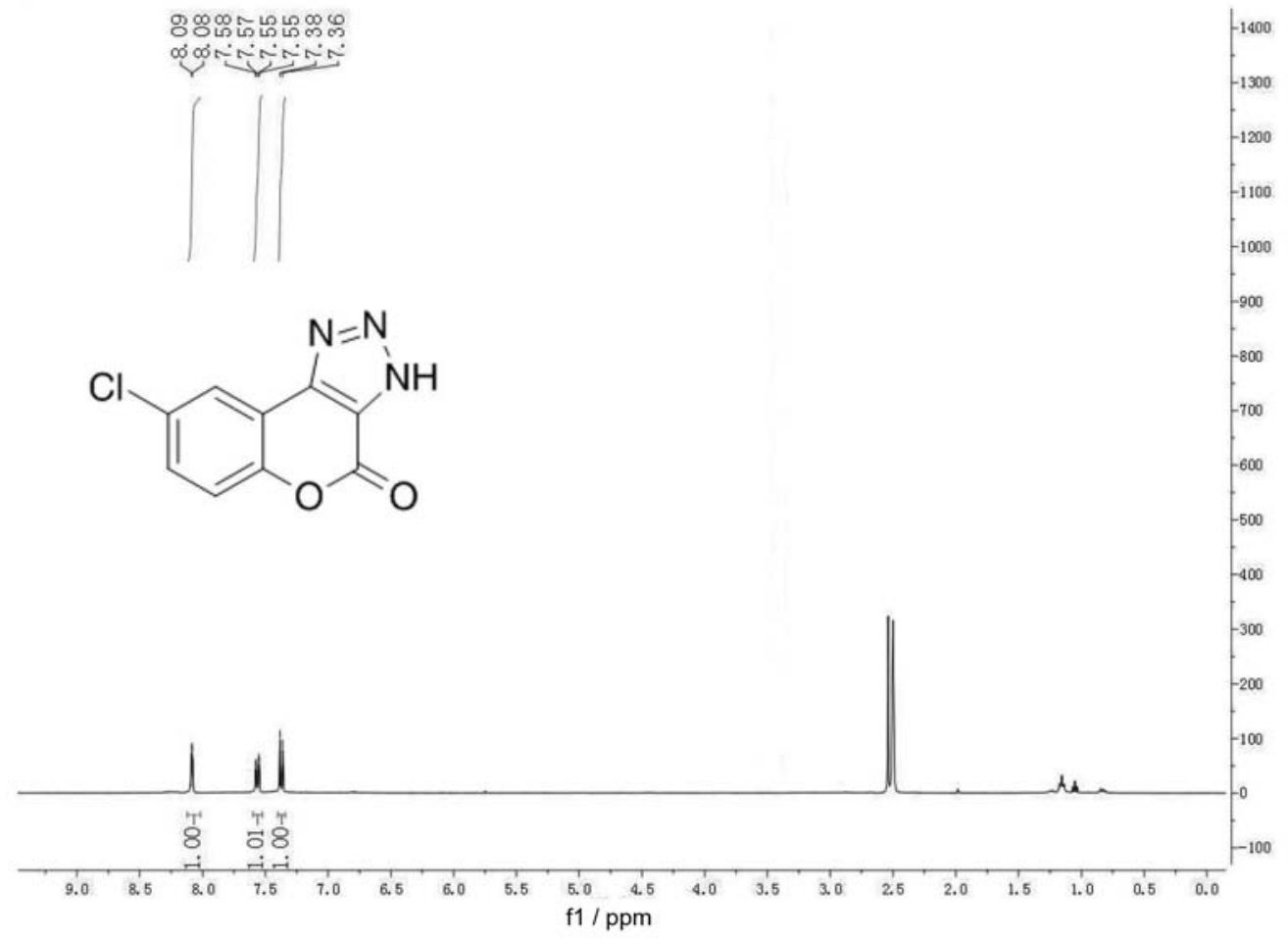

Figure S3. ${ }^{1} \mathrm{H}$ NMR spectrum (400 MHz, DMSO- $d_{6}$ ) of 8-chlorochromeno[3,4-d][1,2,3]triazol-4(3H)-one (2c). 


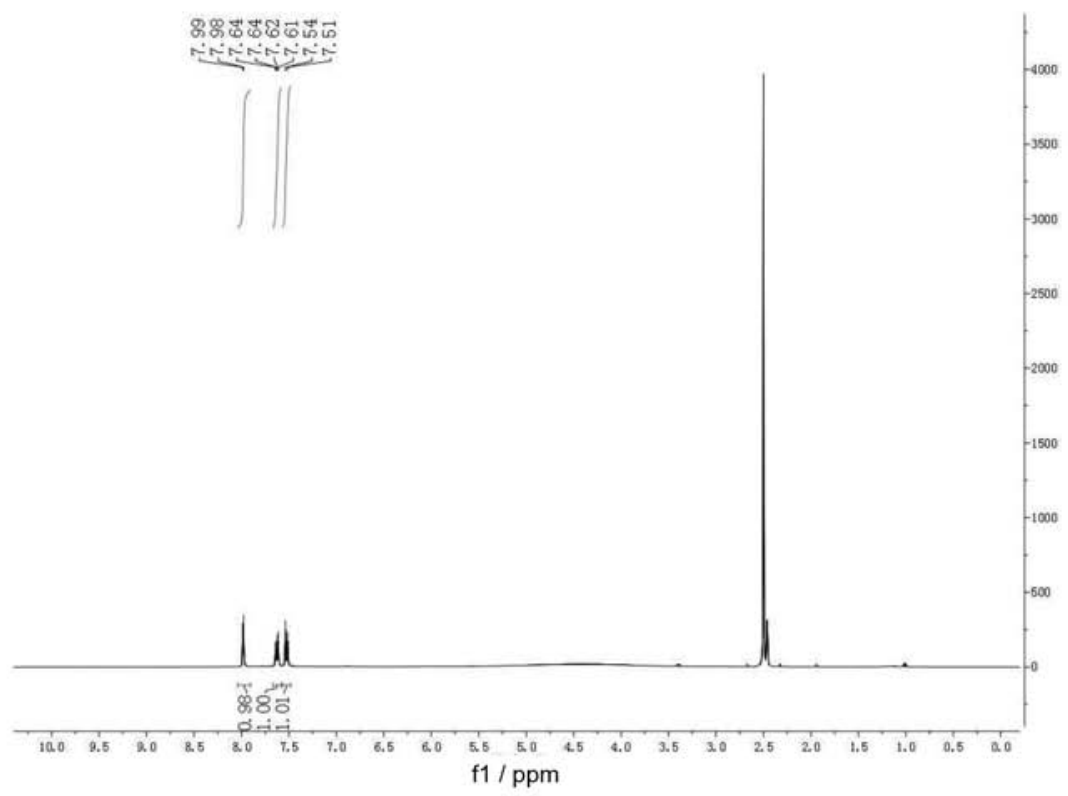

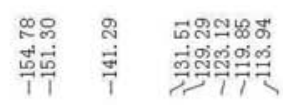<smiles>O=c1oc2ccc(Br)cc2c2nn[nH]c12</smiles>

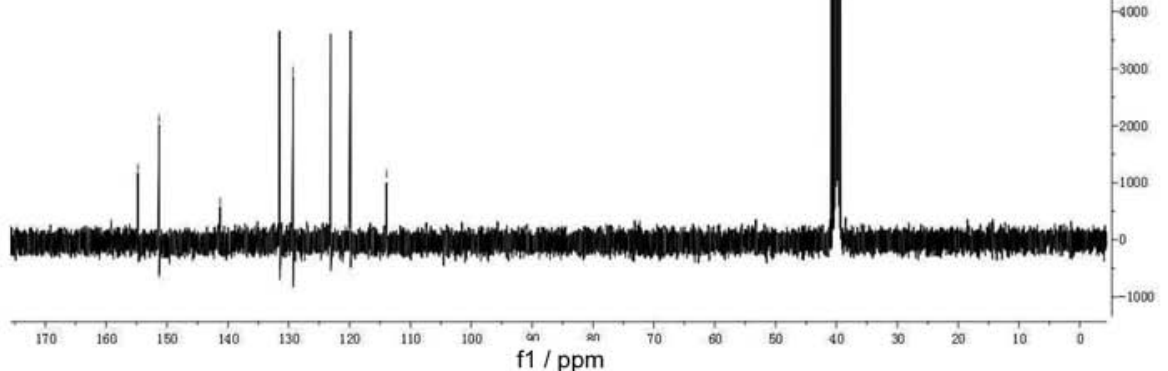

Figure S4. ${ }^{1} \mathrm{H}$ NMR and ${ }^{13} \mathrm{C}$ NMR spectra (400 MHz, DMSO- $d_{6}$ ) of 8-bromochromeno[3,4-d][1,2,3]triazol-4(3H)-one (2d). 


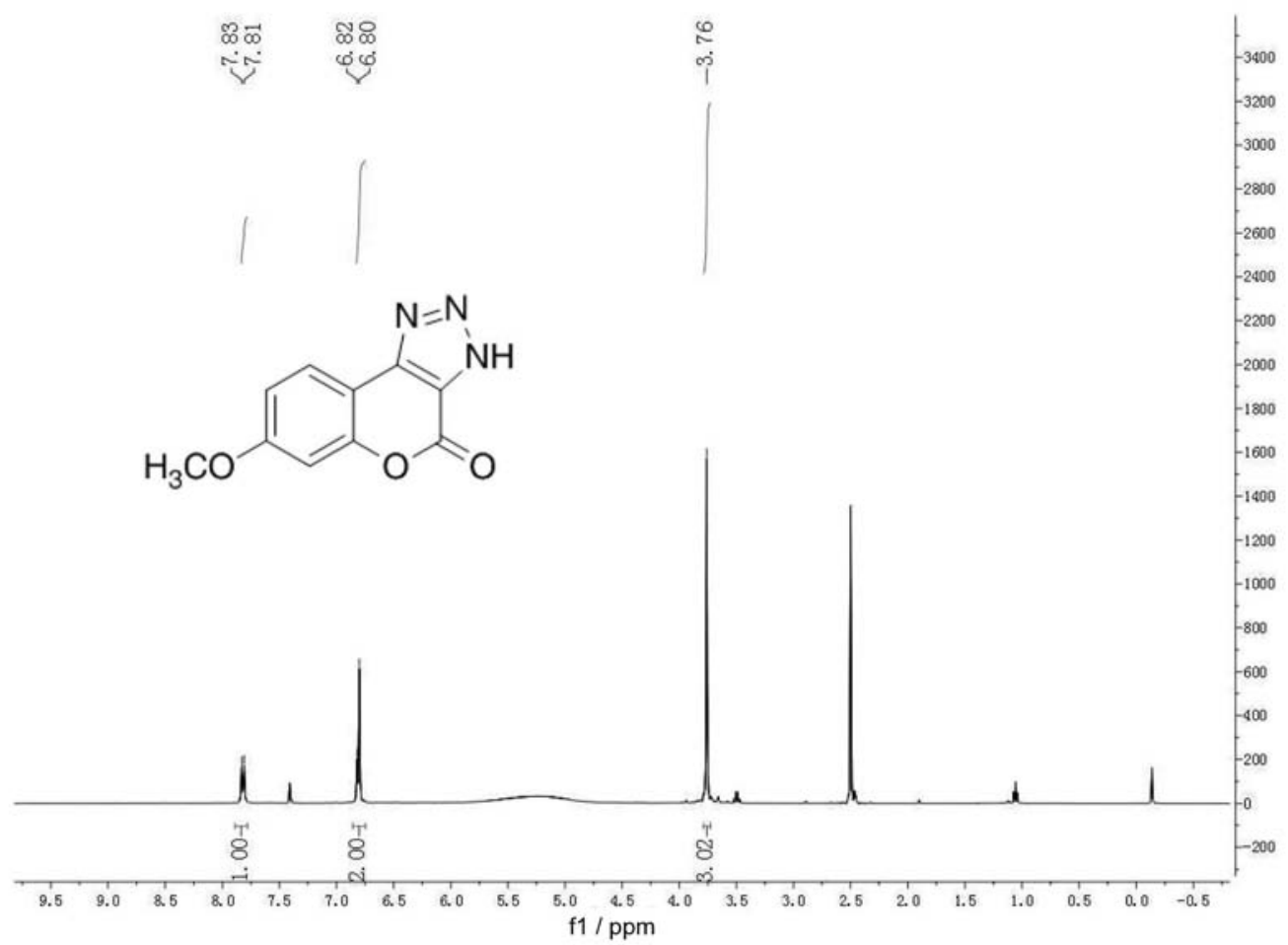

Figure S5. ' $\mathrm{H}$ NMR spectrum (400 MHz, DMSO- $d_{6}$ ) of 7-methoxychromeno[3,4-d][1,2,3]triazol-4(3H)-one (2e).

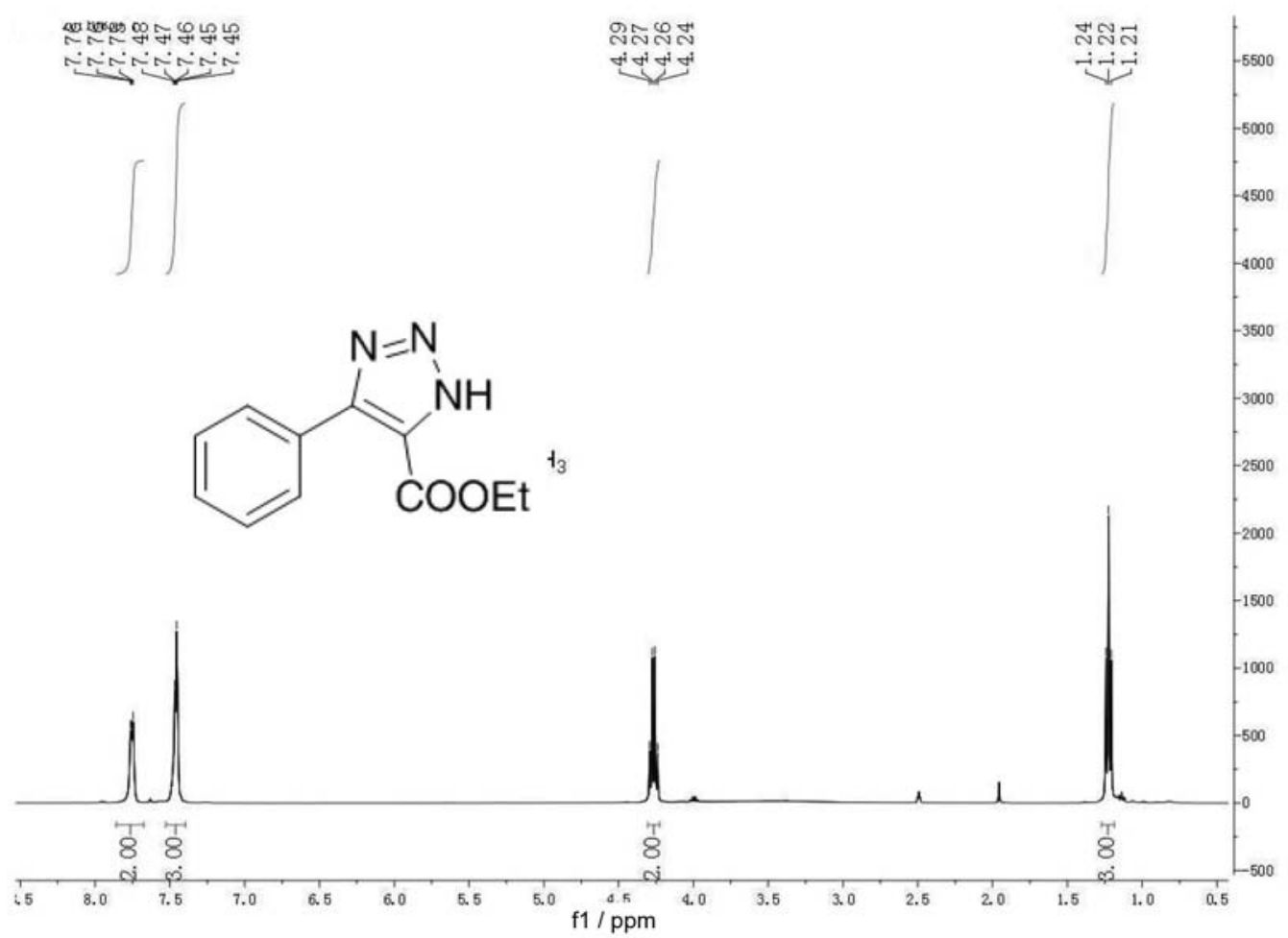

Figure S6. 'H NMR spectrum (400 MHz, DMSO- $d_{6}$ ) of ethyl 5-phenyl-1H-1,2,3-triazole-4-carboxylate (2f). 


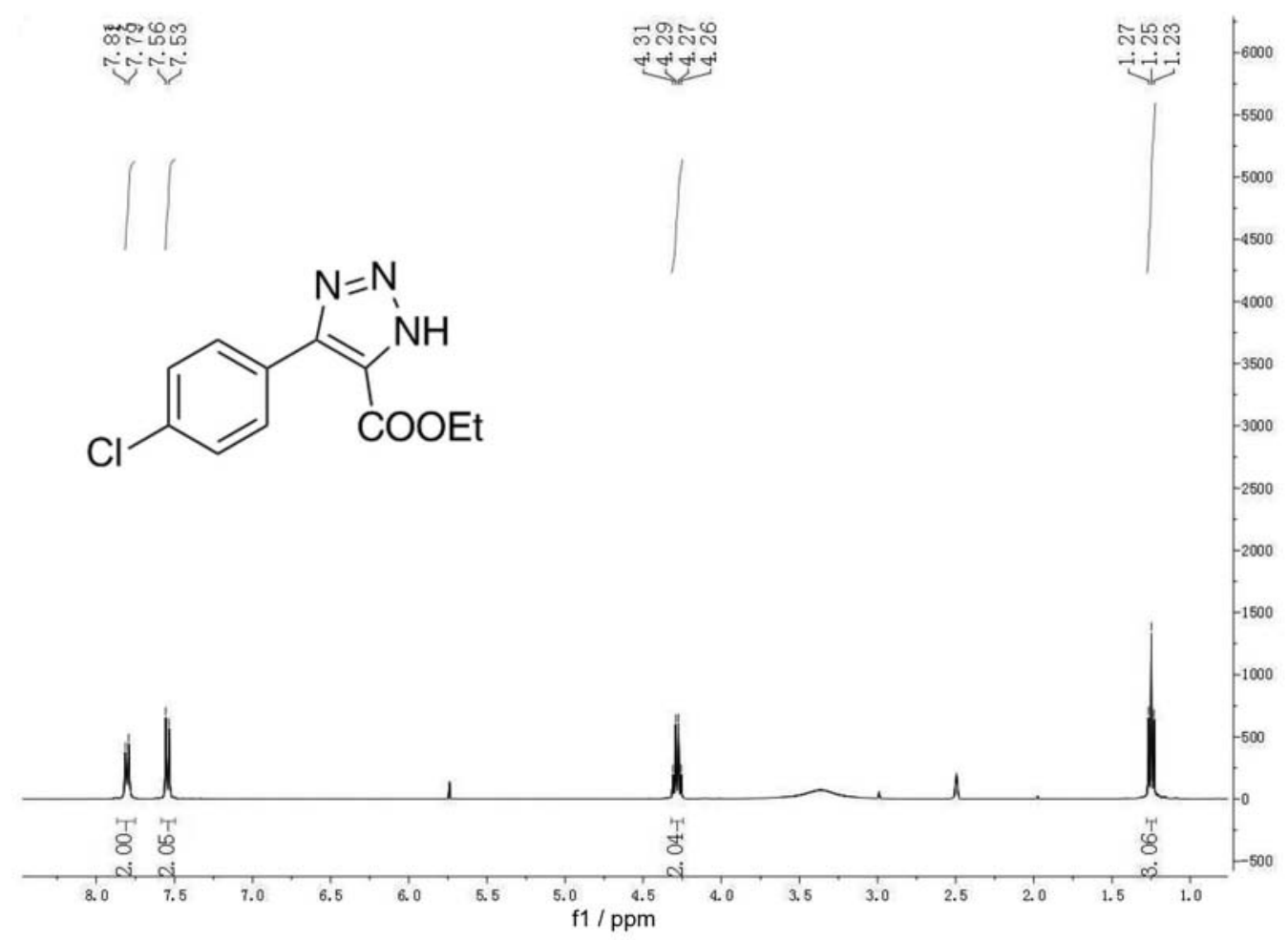

Figure S7. ${ }^{1} \mathrm{H}$ NMR spectrum (400 MHz, DMSO- $d_{6}$ ) of ethyl 5-(4-chlorophenyl)-1H-1,2,3-triazole-4-carboxylate (2g). 

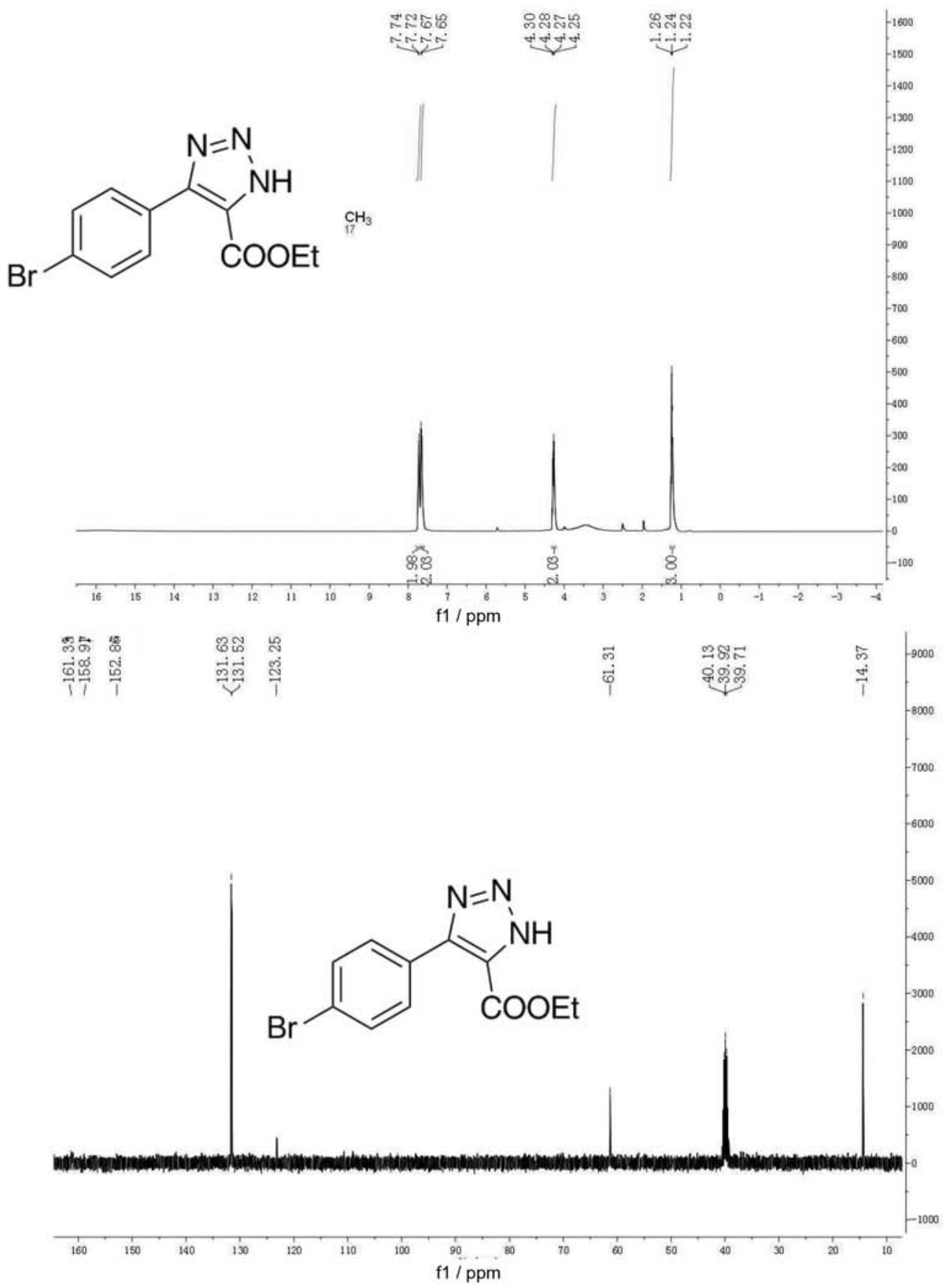

Figure S8. ${ }^{1} \mathrm{H}$ NMR and ${ }^{13} \mathrm{C}$ NMR spectra (400 MHz, DMSO- $d_{6}$ ) of ethyl 5-(4-bromophenyl)-1H-1,2,3-triazole-4-carboxylate (2h). 

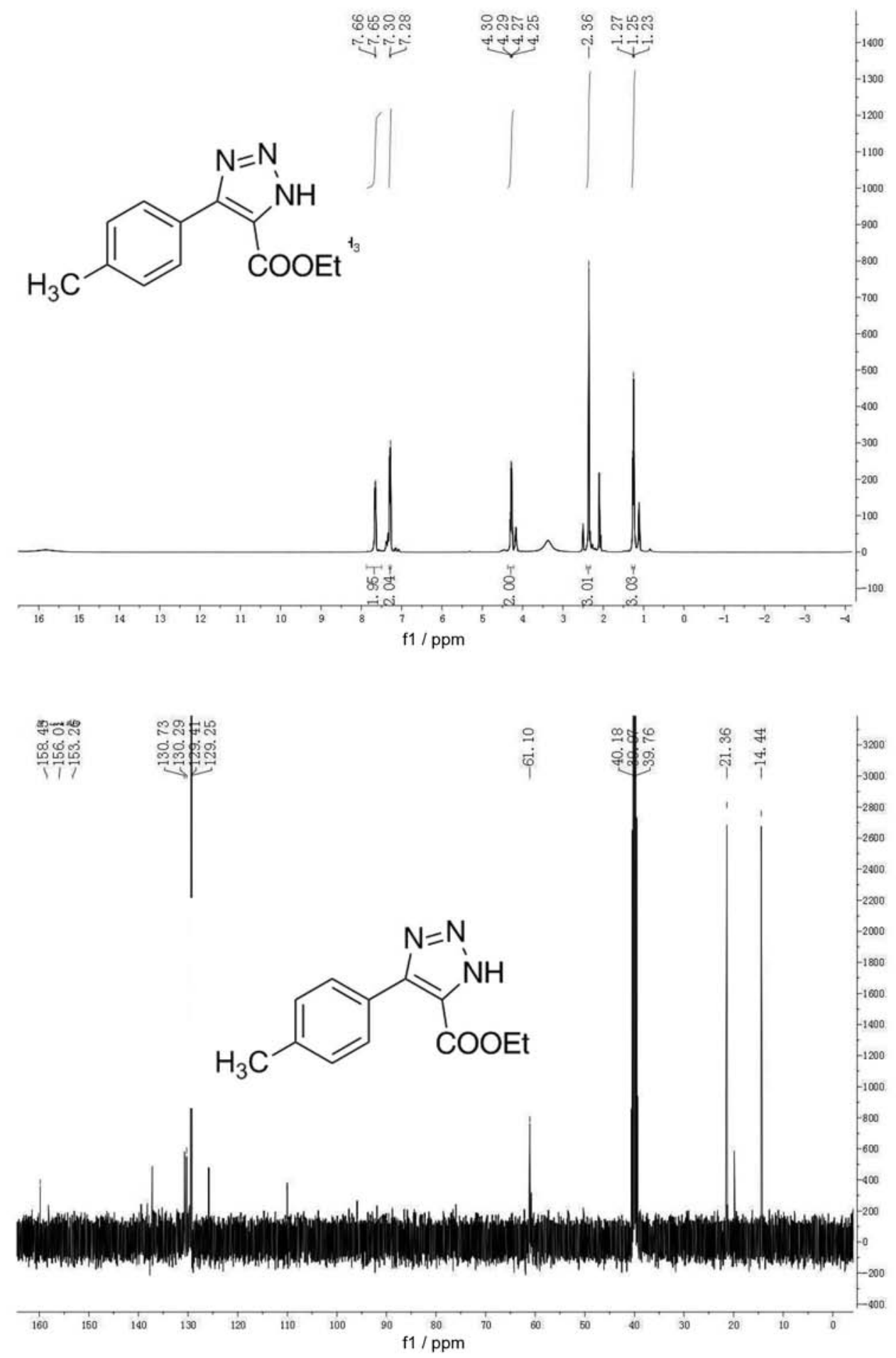

Figure S9. ${ }^{1} \mathrm{H}$ NMR and ${ }^{13} \mathrm{C}$ NMR spectra (400 MHz, DMSO- $d_{6}$ ) of ethyl 5-(p-tolyl)-1H-1,2,3-triazole-4-carboxylate (2i). 

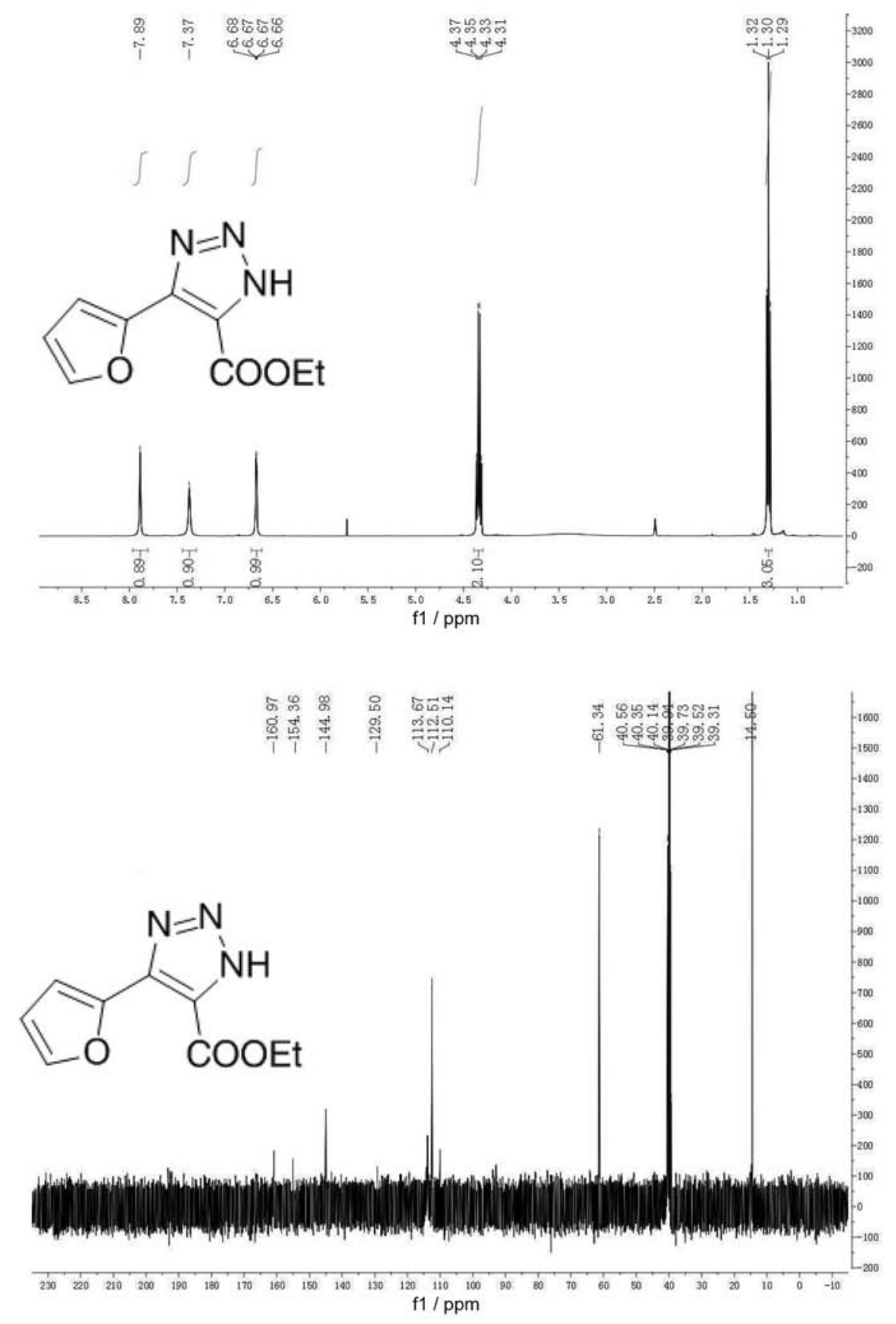

Figure S10. ${ }^{1} \mathrm{H}$ NMR and ${ }^{13} \mathrm{C}$ NMR spectra (400 MHz, DMSO- $d_{6}$ ) of ethyl 5-(furan-2-yl)-1H-1,2,3-triazole-4-carboxylate (2j). 